\title{
Soy Lecithin-Derived Phosphatidylserine Plus Phosphatidic Acid: Effects on Brain Functions in Elderly Patients with Alzheimer's Disease and Dementia
}

\author{
Margret I. Moré ${ }^{1 *}$ and David Rutenberg ${ }^{2}$ \\ ${ }^{1}$ analyze \& realize $\mathrm{GmbH}$, Berlin, Germany \\ ${ }^{2}$ Lipogen Ltd., Haifa, Israe
}

\begin{abstract}
Phosphatidic acid (PA) and phosphatidylserine (PS) and are natural constituents of healthy brain cell membranes, which have been recognized since the 1970s as essential to normal neuronal functioning. PA is a precursor in the formation of other phospholipids, including PS and phosphatidylethanolamine (PE). Also, it has an impact on membrane rigidity/flexibility, which is important in modulating exo- and endocytosis. PS is also an important precursor for PE synthesis. Since PS predominantly occurs in brain cells, but normal diets do not include the consumption of brains, PS is available to our brains mostly via natural "production" in our bodies.
\end{abstract}

Here, we present a tabulated literature survey of clinical studies on PS and/or PA regarding brain function in elderly people. In addition we give a summary on two of our our already published pilot studies performed with a brain-health food supplement containing a proprietary blend of $100 \mathrm{mg}$ PS and $80 \mathrm{mg}$ PA produced from soy lecithin: A three-month double-blind, placebo-controlled study demonstrated the positive influence of three PS+PA capsules/ day, (300 mg PS+240 mg PA per day; $n=40)$ ) or placebo $(n=32)$ on memory and mood in functioning, non-depressive elderly people with memory problems. In a two-month randomized, double-blind, placebo-controlled study, three PS+PA capsules/day (300 mg PS+240 mg PA per day; $n=56)$ or placebo $(n=40)$ improved daily functioning, mental health, emotional state, and self-reported general condition in patients with Alzheimer's disease (AD).

Altogether there is encouraging clinical data that PS+PA supplementation could be beneficial to AD patients and other elderly people with memory or cognition problems. Long-term studies are, however, still lacking.

Keywords: Alzheimer's disease; Cognition; Daily functioning. Dementia; Elderly; Memory; Mood; Phosphatidic acid; Soy lecithinderived phosphatidylserine; MemreePlus ${ }^{\mathrm{TM}}$

\section{Phosphatidylserine (PS) and Phosphatidic Acid (PA) in Memory}

The membrane phospholipids phosphatidic acid (PA) and phosphatidylserine (PS) are essential to cellular functioning, acting as a biological detergent, keeping fatty substances soluble and cell membranes flexible $[1,2]$. During the pathogenesis of several age-related neurodegenerative diseases, including Alzheimer's disease, the neuronal membrane lipid composition is altered in the brain [3,4]. Also, the lipid raft composition appears to be altered in neurodegenerative diseases [5].

PS (and PA), produced by enzymatic conversion of soybean lecithin, avoids possible regulatory and safety issues regarding bovine spongiform encephalopathy. Soy lecithin-derived PS is absorbed and metabolized, with elevated serum levels for at least 1.5 hours after an oral dose, as has been shown within a kinetic study on 8 human volunteers. The baseline serum level of PS in relation to the level of total serum phospholipids was around 2\%. 30 minutes after ingestion, it started to increase, peaking at 90 minutes after intake at around $4 \%$, and returning to the basal level 180 minutes after intake [23].

Recently, oral administration of phosphatidylcholine/phosphatidylethanolamine (PE) -transphosphatidylated PS has been shown to improve memory impairment in aged rats [6]. Also, other experiments have shown an improvement in memory, learning capacity, and other cognitive parameters in PS-supplemented rodents [7-11]. This is plausible, since PS was found to stimulate neurotransmitter release $[7,12]$, increase brain glucose metabolism [13,14] and reduce oxidative stress in the brain [15].

In clinical studies, PS-containing preparations were found to selectively dampen stress levels [16-18], improve learning and perception parameters in children with attention deficit hyperactivity disorder (ADD) [19,20], and improve calculation speed of athletes [21]. Table 1 summarizes previously performed studies on PS and/or PA regarding brain function in the elderly.

\section{Summary of Two Previously Published Pilot Studies on PS \& PA}

In the following, we summarize the clinical results from a recent publication on clinical effects of dietary soy lecithin-derived PS+PA supplementation (manufactured by Lipogen Ltd. (Haifa, Israel) within two placebo-controlled studies on elderly people with memory impairment or dementia [23]. These studies were performed between 1992 and 1999, and were, to our knowledge, the first studies performed with plant-derived PS. For both studies, informed consent of the participants was obtained, and the studies complied with the Helsinki Declaration of 1996. However, an ethics committee vote was omitted since it was not mandatory at the time.

*Corresponding author: Margret I. Moré, analyze \& realize $\mathrm{GmbH}$, Berlin, Germany, Tel: +49-17698175217; Fax: +49 304000 8457; E-mail: mmore@analyze-realize.com

Received April 05, 2017; Accepted May 08, 2017; Published May 09, 2017

Citation: Moré MI, Rutenberg D (2017) Soy Lecithin-Derived Phosphatidylserine Plus Phosphatidic Acid: Effects on Brain Functions in Elderly Patients with Alzheimer's Disease and Dementia. Aging Sci 5: 179. doi: 10.4172/23298847.1000179

Copyright: $\odot 2017$ Moré MI, et al. This is an open-access article distributed unde the terms of the Creative Commons Attribution License, which permits unrestricted use, distribution, and reproduction in any medium, provided the original author and source are credited. 
Citation: Moré MI, Rutenberg D (2017) Soy Lecithin-Derived Phosphatidylserine Plus Phosphatidic Acid: Effects on Brain Functions in Elderly Patients with Alzheimer's Disease and Dementia. Aging Sci 5: 179. doi: 10.4172/2329-8847.1000179

\begin{tabular}{|c|c|c|c|c|c|}
\hline Publication & Study design & Duration & Participants & Oral dosage & Brief outcome summary \\
\hline Zhang et al., 2015 [22] & Controlled study & 12 weeks & $57 \mathrm{AD}$ patients & $300 \mathrm{mg} / \mathrm{d}$ of PS or placebo & $\begin{array}{l}\text { In AD patients, vocabulary and picture } \\
\text { matching scores in the two treatment groups } \\
\text { increased after treatment. Moreover, the } \\
\text { scores in the treated group were significantly } \\
\text { greater than the control group. }\end{array}$ \\
\hline $\begin{array}{l}\text { Moré at al., 2014 [23] } \\
\text { (study in 1992), } \\
\text { Study } 1 \text { summarized } \\
\text { below }\end{array}$ & $\begin{array}{l}\text { Randomized, placebo- } \\
\text { controlled, double-blind } \\
\text { study }\end{array}$ & 3 months & $\begin{array}{l}72 \text { functioning, non-depressive } \\
\text { elderly } \\
\text { ( } 60-80 \text { years) }\end{array}$ & $\begin{array}{l}\text { Soy derived: } \\
100 \mathrm{mg} \text { PS }+80 \mathrm{mg} \text { PA in } \\
\text { lecithin tid or placebo }\end{array}$ & $\begin{array}{l}\text { Significant positive influence of PS on } \\
\text { memory and mood in pre-post comparison }\end{array}$ \\
\hline $\begin{array}{l}\text { Moré at al., } 2014 \text { [23] } \\
\text { (study in 1995), } \\
\text { Study } 2 \text { summarized } \\
\text { below }\end{array}$ & $\begin{array}{l}\text { Randomized, placebo- } \\
\text { controlled, double-blind } \\
\text { study }\end{array}$ & 2 months & $\begin{array}{l}96 \text { patients with } A D \\
\text { ( } 50-90 \text { years) }\end{array}$ & $\begin{array}{l}\text { Soy derived: } \\
100 \mathrm{mg} \text { PS }+80 \mathrm{mg} \text { PA in } \\
\text { lecithin tid or placebo }\end{array}$ & $\begin{array}{l}\text { Significant positive effect on daily functioning, } \\
\text { positive trends on emotional state and on } \\
\text { self-reported general condition, no adverse } \\
\text { effects }\end{array}$ \\
\hline $\begin{array}{l}\text { Moré at al., } 2014 \text { [23] } \\
\text { (study 1991-1999) }\end{array}$ & $\begin{array}{l}\text { Historical prospective } \\
\text { data (discussed) }\end{array}$ & $\begin{array}{l}2 \text { months } \\
\text { to } 13 \text { years } \\
\text { (mean } \\
1.4 \pm 1.8 \\
\text { years) }\end{array}$ & $\begin{array}{l}68 \text { patients with } A D \text {, dementia, } \\
\text { or memory loss (44-92 years) }\end{array}$ & $\begin{array}{l}\text { Soy derived PS+PA } \\
\text { supplementation }\end{array}$ & $\begin{array}{l}\text { No adverse effects, significant positive } \\
\text { influence of PS in most cognitive categories } \\
\text { in pre-post-comparison }\end{array}$ \\
\hline Richter et al., 2013 [24] & Open label & 12-weeks & $\begin{array}{l}30 \text { elderly volunteers with } \\
\text { memory complaints }(50-90 \\
\text { years) }\end{array}$ & $\begin{array}{l}\text { Soy derived PS (100 mg } \\
\text { tid) }\end{array}$ & $\begin{array}{l}\text { PS showed favourable effects on cognitive } \\
\text { function }\end{array}$ \\
\hline $\begin{array}{l}\text { Kato-Kataoka et al., } \\
2010 \text { [25] }\end{array}$ & $\begin{array}{l}\text { Randomized, double- } \\
\text { blind placebo-controlled } \\
\text { study }\end{array}$ & 6 months & $\begin{array}{l}78 \text { elderly people with mild } \\
\text { cognitive impairment }(50-69 \\
\text { years) }\end{array}$ & $\begin{array}{l}\text { Soy derived PS }(100 \mathrm{mg} \\
\text { tid) or placebo }\end{array}$ & $\begin{array}{l}\text { The supplemented subgroup with low } \\
\text { memory scores significantly improved } \\
\text { regarding memory, compared to baseline, } \\
\text { while elderly in the placebo group remained } \\
\text { unchanged }\end{array}$ \\
\hline $\begin{array}{l}\text { Jorissen et al., } 2001 \\
\text { [26]. }\end{array}$ & $\begin{array}{l}\text { Randomized, double- } \\
\text { blind placebo-controlled } \\
\text { study }\end{array}$ & 12 weeks & $\begin{array}{l}120 \text { aged patients with AAMI } \\
(>57 \text { years }) \\
(n=41, \text { PS-group) }\end{array}$ & $\begin{array}{l}100 \text { mg soy derived PS } 6 \\
\text { times daily or placebo }\end{array}$ & $\begin{array}{l}\text { No significant cognitive improvements in any } \\
\text { group }\end{array}$ \\
\hline $\begin{array}{l}\text { Schreiber et al., } 2000 \\
\text { [27] }\end{array}$ & Open label & 12-weeks & 18 AAMI patients (65-78 years) & $\begin{array}{l}\text { plant derived PS (100 mg } \\
\text { tid) }\end{array}$ & Significant positive effects on cognition \\
\hline Heiss et al., 1994 [13] & Controlled study & 6 months & 70 probable $A D$ patients & $\begin{array}{l}2 \times 200 \mathrm{mg} / \text { day PS } \\
+ \text { cognitive training or } \\
\text { pyritinol } 2 \times 600 \mathrm{mg} / \text { day } \\
\text { +cognitive training or } \\
\text { cognitive training only, or } \\
\text { social support only }\end{array}$ & $\begin{array}{l}\text { PS treatment had an effect on different } \\
\text { measures of brain function, with best effects } \\
\text { after } 8 \text { and } 16 \text { weeks. }\end{array}$ \\
\hline $\begin{array}{l}\text { Cenacchi et al., } 1993 \\
\text { [28] }\end{array}$ & $\begin{array}{l}\text { Randomized, double- } \\
\text { blind placebo-controlled } \\
\text { study }\end{array}$ & 6-month & $\begin{array}{l}494 \text { cognitively-impaired elderly } \\
\text { (65-93 years) }\end{array}$ & $\begin{array}{l}300 \text { mg bovine brain- } \\
\text { derived PS daily or } \\
\text { placebo }\end{array}$ & $\begin{array}{l}\text { Significant improvement in behavioural and } \\
\text { cognitive parameters in the supplementation } \\
\text { group }\end{array}$ \\
\hline Engel et al., 1992 [29] & $\begin{array}{l}\text { Double-blind cross-over } \\
\text { study }\end{array}$ & $\begin{array}{l}8 \text { weeks } \\
\text { ( } 8 \text { week } \\
\text { washout } \\
\text { between } \\
\text { treatments) }\end{array}$ & $\begin{array}{l}33 \text { patients with mild primary } \\
\text { degenerative dementia } \\
\text { according to DSM-III }\end{array}$ & $\begin{array}{l}\text { Bovine brain derived PS } \\
(300 \mathrm{mg} / \mathrm{d}) \text { versus placebo }\end{array}$ & $\begin{array}{l}\text { PS reduced the higher power values } \\
\text { compared to placebo, shifting EEG power } \\
\text { more towards the normal level. }\end{array}$ \\
\hline Crook et al., 1991 [43] & $\begin{array}{l}\text { Randomized, double- } \\
\text { blind placebo-controlled } \\
\text { study }\end{array}$ & 12-week & $\begin{array}{l}149 \text { aged patients with AAMI } \\
\text { ( } 50-75 \text { years) }\end{array}$ & $\begin{array}{l}100 \text { mg bovine brain- } \\
\text { derived PS tid or placebo }\end{array}$ & $\begin{array}{l}\text { Supplemented subgroup with low level } \\
\text { performance improved, relative to placebo in } \\
\text { daily life learning and memory tasks }\end{array}$ \\
\hline Fünfgeld et al., 1989 [30] & Open label & $\begin{array}{l}\text { Up to } 18 \\
\text { months }\end{array}$ & $\begin{array}{l}\text { Parkinsonian patients with senile } \\
\text { dementia of Alzheimer's type } \\
\text { (SDAT). }\end{array}$ & $\begin{array}{l}\text { Bovine brain derived PS } \\
(300 \mathrm{mg} / \mathrm{d}) \text { versus placebo }\end{array}$ & $\begin{array}{l}\text { A therapeutic effect of PS was observed: } \\
\text { acceleration of a slowed EEG }\end{array}$ \\
\hline Villardita et al., 1987 [31] & $\begin{array}{l}\text { Randomized, double- } \\
\text { blind placebo-controlled } \\
\text { study }\end{array}$ & 3 months & $\begin{array}{l}170 \text { aged patients with AAMI } \\
\text { (55-80 years) }\end{array}$ & $\begin{array}{l}\text { bovine brain-derived PS, } \\
300 \mathrm{mg} \text { daily or placebo }\end{array}$ & $\begin{array}{l}\text { Improvement on neuropsychological tests in } \\
\text { the PS-supplemented subjects relative the } \\
\text { placebo group }\end{array}$ \\
\hline $\begin{array}{l}\text { Delwaide et al., } 1986 \\
\text { [32] }\end{array}$ & $\begin{array}{l}\text { Randomized, double- } \\
\text { blind placebo-controlled } \\
\text { study }\end{array}$ & 6 weeks & $\begin{array}{l}42 \text { hospitalized demented } \\
\text { patients }\end{array}$ & $\begin{array}{l}3 \times 100 \mathrm{mg} \text { bovine brain } \\
\text { derived PS versus placebo }\end{array}$ & $\begin{array}{l}\text { There was a trend toward improvement in the } \\
\text { PS treated patients; analysis of covariance } \\
\text { showed a significant treatment effect on the } \\
\text { Peri Scale }\end{array}$ \\
\hline
\end{tabular}

AD Alzheimer's disease, AAMI, Age associated memory impairment, PA Phosphatidic acid, PS Phosphatidylserine, tid Three times daily.

Table 1: Overview of clinical studies on PS and/or PA regarding brain function in elderly.

\section{Study 1: Effect of PS+PA on memory and mood in functioning} elderly

In 1992, elderly male and female residents (aged 60-80 years) of three Israeli rural collective communities (Kibbutzim Givat Brenner, Gat, and Galon), with memory problems in daily life were randomly included in this placebo-controlled study. The subjects were not demented, achieving at least 25 out of 30 on the Folstein Mini-Mental
State Examination (MMSE) [33]. Also they were not depressed or suffering from any major disease, and were not taking medication with influence on memory.

For 3 months, the subjects took soy lecithin-derived PS (100 mg) and PA (80 mg) ("L-Telect", Lipogen Ltd., Haifa, Israel; similar to current Lipogen PS Plus $^{\text {tu }} \&$ MemreePlus ${ }^{\text {Tw }}$ ) tid (40 ITT/31PP subjects) or placebo (500 mg lecithin) (32 ITT/26 PP subjects) to evaluate effects 
on memory performance. The Wechsler Memory test (WMT; without age correction) was used to examine memory, learning, association, and information gathering as distinct from intelligence [34]. Both placebo and PS+PA group had (as expected) a significant test-retest improvement in total WMT scores in the testing at the end of the study $(\mathrm{P}<0.005)$. However, the PS+PA group, compared to the placebo group, reached a higher degree of significance, see Figure 1A. In pre- and postcomparison of components of the memory test, none of the placebo group's changes were statistically significant - in contrast, results for maintaining information, visual memory, and memorizing numbers improved with a statistical significance of $\mathrm{P}<0.05$ within the PS+PA group.

When comparing the scores between groups, only trends in favour of the PS+PA group could be observed, possibly due to the rather small study size and its relatively short duration. However, subjects on PS+PA supplementation with a high initial WMT score showed more significant memory improvements, whereas those who had scored low did not, see Figure 1B.

Mood was additionally tested using the LDS [35]. The resulting score was also used to exclude those with a score of $<17$ during recruitment. Subjects in the PS+PA group did not have any significant mood changes from baseline (late summer/early fall) to the end of the study in (late fall/winter), however in the placebo group a seasonally expected mood deterioration was observed ( $\mathrm{P}<0.001$ in pre-post comparison). This is consistent with a different report that PS had a positive effect on geriatric depression [36].

\section{Study 2: Effect of PS+PA on daily functioning and general condition in 96 patients with AD}

A two-month double-blind, randomized, placebo-controlled trial was performed on patients diagnosed with definite-probable $\mathrm{AD}$ (Alzheimer's Disease and Related Disorders Association) in 1995. Men and women aged 50-90 years were recruited from the Kaplan Medical Centre (Rehovot, Israel), from kibbutzim near Rehovot, and the Israel Association of Alzheimer's Disease. 56 patients were allocated to 100 mg of PS+80 mg PA mixed with lecithin tid ("L-Telect", Lipogen Ltd., Haifa, Israel) (53 PP patients); 40 patients to placebo (starch) (39 PP patients). The two randomized groups were comparable at baseline.

PS+PA had clear beneficial effects in patients with dementia, especially if the expected gradual cognitive deterioration is taken into consideration:
The 7-ADLs functioning index includes general self-reporting and scoring of activities of daily living (Table 2) [48]. In the PS+PA group, no progression of the deterioration of daily functioning was observed, compared to a decline in the control group $(\mathrm{P}=0.039)$.

The Folstein MMSE [33] was used to examine the mental status before and after supplementation. A slight and non-significant improvement in both groups $(\mathrm{P}=0.872)$ could be detected. $23.5 \%$ of the PS+PA group showed an improvement from abnormal $(\leq 23)$ baseline scores to normal scores $(<23)$ following supplementation, compared to 4 of $35(11.4 \%)$ in the placebo group. Also, a positive trend in favour of the $\mathrm{PS}+\mathrm{PA}$ group $(\mathrm{P}=0.156)$ could be observed when comparing the means of the index of emotional state (simplified Tel-Aviv University Rosen Target Detection Test [35]).

Another positive trend was observed in the self-reported general condition: $49.0 \%$ of the PS+PA group reported an improvement compared to $26.3 \%$ in placebo group $(\mathrm{P}=0.084)$.

A post-trial (patient-funded) consumption rate of $42.9 \%$ of the PS+PA group ( 6 of 14 assessed patients) versus 0 of 11 placebo patients $(\mathrm{P}=0.010)$ additionally indicated the beneficial effects of PS+PA in patients with $\mathrm{AD}$. It should be noted that another 3 assessed patients were unable to continue consumption because of inability to purchase PS+PA.

PS+PA had an excellent tolerability: $88.2 \%$ of the patients on PS+PA and $91.1 \%$ on placebo did not report any side effects. The remaining could either not remember or had sensations which could not be correlated to the supplementation.

Altogether, the published results [23] suggest that PS+PA can

\begin{tabular}{|c|c|c|c|}
\hline \multicolumn{4}{|c|}{ Before-after comparison } \\
\hline & PS+PA & Placebo & $P$ value \\
\hline Baseline & $6.23 \pm 1.98$ & $5.62 \pm 2.42$ & 0.433 \\
\hline After 2 months & $6.23 \pm 2.19$ & $4.90 \pm 3.00$ & 0.021 \\
\hline Difference & $0.00 \pm 0.52$ & $-0.72 \pm 2.05$ & 0.039 \\
\hline \multicolumn{4}{|c|}{ Change pattern analysis } \\
\hline & PS+PA & Placebo & $P$ value \\
\hline Deterioration & $3.8 \%$ & $17.9 \%$ & \multirow{3}{*}{$\begin{array}{c}0.066 \\
\text { (positive trend in } \\
\text { favour of } P S+P A \text { ) }\end{array}$} \\
\hline Stability & $90.6 \%$ & $79.5 \%$ & \\
\hline Improvement & $5.6 \%$ & $2.6 \%$ & \\
\hline
\end{tabular}

Table 2: Comparison of 7-ADL functioning index (Study 2), adapted from [23]

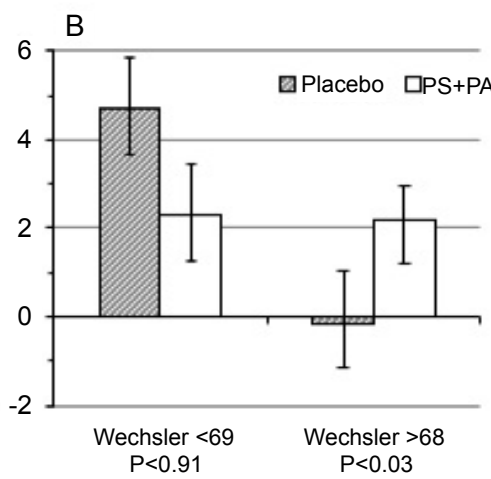

Figure 1: a) The PS+PA group, compared to the placebo group, reached a higher degree of significance, b) Subjects on PS+PA supplementation with a high initial WMT score showed more significant memory improvements. Study 1 , adapted from [23]. 
support memory and cognitive function, especially in people with cognition and memory deficiencies. Possibly, significance in some of the parameters was not reached due to the short study duration and the limited sample size. Similarly, encouraging results were also published in a number of other studies (Table 1).

\section{Discussion}

Regarding elderly people with memory impairment or dementia, there are promising clinical data, especially for the supplementation of PS (Table 1). In addition, there is an emerging understanding on how the phospholipid pattern is linked to brain function, or its decline: Mild cognitive impairment and $\mathrm{AD}$ have been linked to oxidative stress and corresponding lipid peroxidation within the brain [37]. Oxidative stress on neuronal membranes also has a detrimental effect on synaptosomal PS asymmetry, which is normally maintained by the ATP-requiring enzyme flippase [38]. Accordingly, the appearance of PS in the outer membrane leaflet is a signal of synaptosomal apoptosis, which was also observed in brain post-mortem autopsies of patients with mild cognitive impairment and AD [39]. Next to the PS distribution, also its overall level is likely to have an impact: In PC12 cells with induced apoptosis, a reduction in the level of PS was detectable before the detection of apoptosis [40].

The supplementation of PS may also have an impact on PE levels, since in mammalian cells PE is synthesized also by PS decarboxylation in the mitochondria [41]. PA is not only a precursor for other phospholipids, but also plays a pivotal role by influencing membrane fluidity, which is especially important for vesicle formation, e.g. during neurotransmission [42]. However there is only limited clinical evidence regarding PA supplementation in elderly people with dementia or age associated memory impairment.

Altogether, long-term investigations on PS+PA supplementation are needed. In most countries, regulatory issues prevent the supplementation of PS+PA for patients with $\mathrm{AD}$, since this is a medical indication - this problem could only be solved by adapting regulations, or by including PS and PA into a drug product, and filing a full drug dossier, which in turn will require more extensive clinical studies.

\section{Author Contributions and Conflict of Interest}

The results on plant derived PS+PA were previously reported [23].

Here, we summarize our main findings and give an update on related literature. The authors cooperated on writing this article. D. Rutenberg in an employee of Lipogen Ltd (Haifa, Israel), M. I. Moré, is an employee of analyze \& realize $\mathrm{GmbH}$, Berlin, Germany.

\section{References}

1. Calderini G (1985) Phospholipids as a pharmacological tool in the aging brain. in Phospholipids in the nervous system, physiological roles, L. Horrocks, J. Kanfer, and G. Porcellati, Editors Raven Press: New York. 11-19.

2. Mozzi R, Buratta S, Goracci G (2003) Metabolism and functions of phosphatidylserine in mammalian brain. Neurochem Res 28: 195-214.

3. Hancock SE, Friedrich MG, Mitchell TW, Truscott RJ, Else PL (2017) The phospholipid composition of the human entorhinal cortex remains relatively stable over 80 years of adult aging. Geroscience 39: 73-82

4. Aureli M, Grassi S, Prioni S, Sonnino S, Prinetti A, (2015) Lipid membrane domains in the brain. Biochim Biophys Acta 1851: 1006-1016.

5. Marin R, Fabelo N, Martín V, Garcia-Esparcia P, Ferrer I, et al. (2017) Anomalies occurring in lipid profiles and protein distribution in frontal cortex lipid rafts in dementia with Lewy bodies disclose neurochemical traits partially shared by Alzheimer's and Parkinson's diseases. Neurobiol Aging 49: 52-59.
6. Lee B, Sur BJ, Han JJ, Shim I, Her S, et al. (2015) Oral administration of squid lecithin-transphosphatidylated phosphatidylserine improves memory impairment in aged rats. Prog Neuropsychopharmacol Biol Psychiatry 56: 1-10.

7. Suzuki S, Yamatoya H, Sakai M, Kataoka A, Furushiro M, et al. (2001) Oral administration of soybean lecithin transphosphatidylated phosphatidylserine improves memory impairment in aged rats. J Nutr 131: 2951-2956.

8. Blokland A, Honig W, Brouns F, Jolles J (1999) Cognition-enhancing properties of subchronic phosphatidylserine (PS) treatment in middle-aged rats: comparison of bovine cortex PS with egg PS and soybean PS. Nutrition 15 778-783.

9. Furushiro M, S Suzuki , Y Shishido, M Sakai , H Yamatoya, et al. (1997) Effects of oral administration of soybean lecithin transphosphatidylated phosphatidylserine on impaired learning of passive avoidance in mice. Jpn J Pharmacol 75: 447-450.

10. Lee B, Sur BJ, Han JJ, Shim I, Her S, et al. (2010) Krill phosphatidylserine improves learning and memory in Morris water maze in aged rats. Progress in neuro-psychopharmacology \& biological psychiatry 34: 1085-1093.

11. Zanotti A, Valzelli L, Toffano G (1989) Chronic phosphatidylserine treatment improves spatial memory and passive avoidance in aged rats. Psychopharmacology 99: 316-321.

12. Nishizuka $Y$ (1984) Turnover of inositol phospholipids and signal transduction Science 225: 1365-1370.

13. Heiss WD, Kessler J, Mielke R, Szelies B, Herholz K, (1994) Long-term effects of phosphatidylserine, pyritinol, and cognitive training in Alzheimer's disease. A neuropsychological, EEG, and PET investigation. Dementia 5: 88-98.

14. Klinkhammer P, Szelies B, Heiss WD (1990) Effect of Phosphatidylserine on Cerebral Glucose Metabolism in Alzheimer's Disease. Dementia 1: 197-201.

15. Chaung HC, Chang CD, Chen PH, Chang CJ, Liu SH, et al. (2013) Docosahexaenoic acid and phosphatidylserine improves the antioxidan activities in vitro and in vivo and cognitive functions of the developing brain. Food chemistry 138: 342-347.

16. Hellhammer J, Fries E, Buss C, Engert V, Tuch A, et al. (2004) Effects of soy lecithin phosphatidic acid and phosphatidylserine complex (PAS) on the endocrine and psychological responses to mental stress. Stress 7: 119-126.

17. Hellhammer J, Hero T, Franz N, Contreras C, Schubert M (2012) Omega-3 fatty acids administered in phosphatidylserine improved certain aspects of high chronic stress in men. Nutrition research 32: 241-250.

18. Hellhammer J, Vogt D, Franz N, Freitas U, Rutenberg D (2014) A soy-based phosphatidylserine/ phosphatidic acid complex (PAS) normalizes the stress reactivity of hypothalamus-pituitary-adrenal-axis in chronically stressed male subjects: a randomized, placebo-controlled study. Lipids Health Dis 13: 121.

19. Hirayama S, Terasawa K, Rabeler R, Hirayama T, Inoue T, et al. (2014) The effect of phosphatidylserine administration on memory and symptoms of attention-deficit hyperactivity disorder: a randomised, double-blind, placebocontrolled clinical trial. J Hum Nutr Diet 284-291.

20. Manor I, Magen A, Keidar D, Rosen S, Tasker H, et al. (2012) The effect of phosphatidylserine containing Omega3 fatty-acids on attention-deficit hyperactivity disorder symptoms in children: a double-blind placebo-controlled trial, followed by an open-label extension. Eur Psychiatry 27: 335-342.

21. Parker AG, Gordon J, Thornton A, Byars A, Lubker J, et al. (2011) The effects of IQPLUS Focus on cognitive function, mood and endocrine response before and following acute exercise. J Int Soc Sports Nutr 8: 16

22. Zhang YY, Yang LQ, Guo LM Guo (2015) Effect of phosphatidylserine on memory in patients and rats with Alzheimer's disease. Genet Mol Res 14: 9325-9333.

23. More MI, Freitas U, Rutenberg D (2014) Positive effects of soy lecithinderived phosphatidylserine plus phosphatidic acid on memory, cognition daily functioning, and mood in elderly patients with Alzheimer's disease and dementia. Adv Ther 31: 1247-1262.

24. Richter Y, Herzog Y, Lifshitz Y, Hayun R, Zchut S (2013) The effect of soybeanderived phosphatidylserine on cognitive performance in elderly with subjective memory complaints: a pilot study. Clin Interv Aging 8: 557-563.

25. Kato-Kataoka A, Sakai M, Ebina R, Nonaka C, Asano T, et al. (2010) Soybeanderived phosphatidylserine improves memory function of the elderly Japanese subjects with memory complaints. J Clin Biochem Nutr 47: 246-255. 
Citation: Moré Ml, Rutenberg D (2017) Soy Lecithin-Derived Phosphatidylserine Plus Phosphatidic Acid: Effects on Brain Functions in Elderly Patients with Alzheimer's Disease and Dementia. Aging Sci 5: 179. doi: 10.4172/2329-8847.1000179

Page 5 of 5

26. Jorissen BL, Brouns F, Van Boxtel MP, Ponds RW, Verhey FR, et al. (2001) The influence of soy-derived phosphatidylserine on cognition in age-associated memory impairment. Nutr Neurosci 4: 121-134.

27. Schreiber S, Kampf-Sherf O, Gorfine M, Kelly D, Oppenheim Y, et al. (2000) An open trial of plant-source derived phosphatydilserine for treatment of agerelated cognitive decline. The Israel journal of psychiatry and related sciences 37: 302-307.

28. Cenacchi T, Bertoldin T, Farina C, Fiori MG, Crepaldi G (1993) Cognitive decline in the elderly: a double-blind, placebo-controlled multicenter study on efficacy of phosphatidylserine administration. Aging 5: 123-133.

29. Engel RR, Satzger W, Günther W, Kathmann N, Bove D, et al. (1992) Doubleblind cross-over study of phosphatidylserine vs. placebo in patients with early dementia of the Alzheimer type. Eur Neuropsychopharmacol 2: 149-155.

30. Fünfgeld EW, Baggen M, Nedwidek P, Richstein B, Mistlberger G (1989) Double-blind study with phosphatidylserine (PS) in parkinsonian patients with senile dementia of Alzheimer's type (SDAT). Prog Clin Biol Res 317: 12351246.

31. Villardita C (1987) Multicentre clinical trial of brain phosphatidylserine in elderly patients with intellectual deterioration. Clin Trials J 24: 84-93.

32. Delwaide PJ, Gyselynck-Mambourg AM, Hurlet A, Ylieff M (1986) Double-blind randomized controlled study of phosphatidylserine in senile demented patients. Acta Neurol Scand 73: 136-140.

33. Folstein MF, Folstein SE, McHugh PR (1975) Mini mental state; a practical method for grading the cognitive state of patients for the clinician. J Psychiatr Res 12: 189-198.

34.https://books.google.co.in/books/about/Assessing the elderly. html?id=rYRHAAAAMAAJ\&redir_esc=y
35. Tel-Aviv University - Psychology, List of Depressive Symptoms (LDS) (1981) Dept of Psychology, Unit of adulthood \& aging, Tel-Aviv University

36. Maggioni M, Picotti GB, Bondiolotti GP, Panerai A, Cenacchi T, et al. (1990) Effects of phosphatidylserine therapy in geriatric patients with depressive disorders. Acta Psychiatr Scand 81: 265-270.

37. Manoharan S, Guillemin GJ, Abiramasundari RS, Essa MM, Akbar M et al. (2016) The Role of Reactive Oxygen Species in the Pathogenesis of Alzheimer's Disease, Parkinson's Disease, and Huntington's Disease: A Min Review. Oxid Med Cell Longev 2016: 8590578.

38. Mohmmad Abdul H, Butterfield DA (2005) Protection against amyloid beta-peptide (1-42)-induced loss of phospholipid asymmetry in synaptosomal membranes by tricyclodecan-9-xanthogenate (D609) and ferulic acid ethyl ester: implications for Alzheimer's disease. Biochim Biophys Acta 1741: 140-148.

39. Bader Lange ML, Cenini G, Piroddi M, Abdul HM, Sultana R, et al. (2008) Loss of phospholipid asymmetry and elevated brain apoptotic protein levels in subjects with amnestic mild cognitive impairment and Alzheimer disease. Neurobiol Dis 29: 456-464.

40. Corsetto PA, Ferrara G, Buratta S, Urbanelli L, Montorfano G, et al. (2016) Changes in Lipid Composition During Manganese-Induced Apoptosis in PC12 Cells. Neurochem Res 41: 258-269.

41. Vance JE, Tasseva G (2013) Formation and function of phosphatidylserine and phosphatidylethanolamine in mammalian cells. Biochim Biophys Acta 1831 543-454.

42. Raben DM, Barber CN (2017) Phosphatidic acid and neurotransmission. Adv Biol Regul 63: 15-21.

43. Crook TH, Tinklenberg J, Yesavage J, Petrie W, Nunzi MG, et al. (1991) Effects of phosphatidylserine in age-associated memory impairment. Neurology 41 644-649. 